\title{
THE GENUS BRYOERYTHROPHYLLUM (MUSCI, POTTIACEAE) IN ANTARCTICA
}

\author{
PHILIP SOLLMAN
}

\begin{abstract}
Antarctic material of the genus Bryoerythrophyllum P. C. Chen was studied from all specimens present in KRAM. Bryoerythrophyllum recurvirostrum (Hedw.) P. C. Chen var. antarcticum L. I. Savicz \& Smirnova is treated as a distinct species: B. antarcticum (L. I. Savicz \& Smirnova) P. Sollman, stat. nov. Three species are now known in the Antarctic region: B. antarcticum, B. recurvirostrum and B. rubrum (Jur. ex Geh.) P. C. Chen. Bryoerythrophyllum rubrum is reported for the first time from the Antarctic. It is a bipolar species. A key to the taxa is given. These species are described and briefly discussed, with notes on illustrations, reproduction, habitat, world range, distribution and elevation in Antarctica.
\end{abstract}

Key words: Antarctica, Bryoerythrophyllum, Bryoerythrophyllum antarcticum, Bryophyta, distribution, taxonomy

Philip Sollman, Notarisappel 2, 9076 LB St. Anna Parochie, The Netherlands; e-mail: a.sollman@hetnet.nl

\section{INTRODUCTION}

When Illustrated Moss Flora of Antarctica (Ochyra et al. 2008) was published I was puzzled by the text and figures (pp. 328-334) for Bryoerythrophyllum recurvirostrum (Hedw.) P. C. Chen. It seemed possible that more than one taxon of subantarctic islands was subsumed under that name. This led me to study all the Bryoerythrophyllum P. C. Chen material present in KRAM (Kraków, Poland).

\section{MATERIALS AND METHODS}

I studied ca 90 Antarctic Bryoerythrophyllum collections from KRAM, examining their anatomy and morphology several times by standard methods. Also examined was type material of $B$. recurvirostrum var. antarcticum and B. rubrum, as well as type material of Barbula brachyphylla Sull. in Whipple, Barbula byrdii E. B. Bartram and Didymodon gelidus Cardot. All the Bryoerythrophyllum material present in L (Leiden) was also examined in recent years, including much material of $B$. recurvirostrum, and smaller-sized material of Bryoerythrophyllum rubrum from Central Europe (Austria). This smaller-sized material also occurs in Antarctic regions.

Five collections of each species were fully analyzed, described and measured. These data are combined in the descriptions below. This paper follows the framework of Illustrated Moss Flora of Antarctica (Ochyra et al. 2008). Citations of authors of botanical names follow Brummitt and Powell (1992).

\section{KEY TO THE ANTARCTIC SPECIES OF BRYOERYTHROPHYLLUM}

Notes ON USING THE KEY. Examine a representative number of leaves or plants, and especially larger, fully grown leaves. In several cases the dentation at the extreme apex is clearly present only on some (younger) leaves. The key below is based only on Antarctic material present in KRAM.

1. Plants growing in very compact, low $(1.0-2.0 \mathrm{~cm})$ red-brown tufts to sods; leaves ovate, entire at apex; plants with distinct small leafy shoots, arising especially from upper part of stems; rhizoids scattered along whole stem; leaves incurved when dry, not crisped; fruits unknown, monoicous . ......... ..................... B. antarcticum

1. Plants growing in looser tufts, often somewhat higher (to $3.5 \mathrm{~cm}$ ); extreme leaf apex often indented or small dentate without small leafy shoots; rhizoids only present along the lower basal parts of stem; leaves \pm crisped when dry; fruiting or not; monoicous or dioicous ...................... 2 
2. Plants usually fruiting; expanded base of leaves not pronounced, to $20-30 \%$ of leaf length; wet leaves straight, at $20-45^{\circ}$ angle to stem, not or hardly curved; costa ending somewhat below apex; leaf apex commonly small, rounded; leaf usually lingulate, from oblong base; costa at base $60-80 \mu \mathrm{m}$ wide; monoicous ....... B. recurvirostrum

2. Fruiting plants not known from Antarctica; leaves sheathing at base, especially pronounced on larger leaves, to $50 \%$ of leaf length; wet and dry leaves often distinctly curved in upper part; leaves above sheath tapering, very often to a small acuminate apex; costa ending with apex, in some leaves excurrent in a shorter or longer awn; leaf usually lanceolate; costa at leaf base 100-130 $\mu \mathrm{m}$ wide; dioicous

B. rubrum

\section{RESULTS AND DISCUSSION}

1. Bryoerythrophyllum antarcticum (L. I. Savicz \& Smirnova) P. Sollman, stat. nov.

BASIONYM: Bryoerythrophyllum recurvirostrum (Hedw.) P. C. Chen var. antarcticum L. I. Savicz \& Smirnova, Bot. Zhurn. (Moscow \& Leningrad) 48: 356, figs $1 \& 2$. 1963.

TyPE: East Antarctica, Bunger Oasis, W of station, on stony floor of valley with rivulet, associated with Schistidium and Bryum algens, 24.1.1956, E.S. Korotkevicz 2/3, det. L. I. Savicz \& Smirnova (ex hb. LE, hb. KRAM, ISOTYPE!).

Plants growing in very dense, compact, low, dark reddish brown tufts. Stems erect, usually branched, especially ramified near apex, 1.2-2.4 $(-2.8) \mathrm{cm}$ high, rounded in transverse section, with large central strand with smaller cells, without epidermis; rhizoids scattered through the whole stem in moderately dense clusters, brown, smooth, branched, younger rhizoids lighter, the oldest darker brown and slightly papillate. Asexual propagation with rhizoidal tubers underground, infrequent (?) on lower, smaller rhizoids, 60$220 \mu \mathrm{m}$ long, in uniseriate rows of $1-6$ cells or multicellular, \pm rounded to irregular, rarely starshaped, each cell ca $13 \times 10 \mu \mathrm{m}$ in diameter, light brown, smooth, somewhat transparent, bulging; very often with tiny leafy shoots, easily breakable, leaflets very often remotely placed, arising from upper parts of stems, the lowest leaflets scaly and often with blunt apex, ecostate or weakly costate, with smooth cells, leaflet margins not or weakly recurved below, upwards leaflets apiculate near apex, with some papillae, also with shoots developing gradually larger papillate leaves upwards (papillae as on main stem); axillary gemmae not seen; axillary hairs hyaline, 7-8 cells long in one row, each cell $c a$ 4-5:1, the lower ones smaller, slightly brownish. Leaves regularly placed along the stem, ovate, (700-)1000-1600(-1700) $\mu \mathrm{m}$ long, (440-) 460-480(-520) $\mu \mathrm{m}$ wide at base, longitudinally symmetrical, apex sometimes somewhat curved, leaves from an oblong base gradually becoming smaller towards apex, when dry erect and incurved, tightly adpressed to stem to somewhat spreading, when wet upper part erect spreading $\mathrm{ca} 30^{\circ}$, unistratose throughout, somewhat concave, often keeled, unbroken, decurrent wings nil, apex smaller to broadly acute to blunt, at least some leaves with 1-3 smooth, hyaline to light brown apical cells, apex without teeth; margins of larger leaves usually small recurved, 1(2) cells broad from above base to apex, sometimes partly recurved only around the middle or plain, not bordered; costa subpercurrent to percurrent, at base (60-)80-100(-120) $\mu \mathrm{m}$ wide, brown, smooth below, slightly smaller towards apex, covered ventrally upwards with quadrate papillate cells, dorsally smooth below, upwards papillate (papillae as on lamina), reniform in transverse section, strongly convex dorsally, flat ventrally with median row of $3-4(-5)$ large, hyaline guide cells in one row and weakly developed or often reduced ventral stereid band, more distinct at dorsal side, with distinct epidermis cells on ventral side; upper lamina cells in surface view commonly quadrate, somewhat rounded, evenly moderately thick-walled, in longitudinal rows, opaque, 4-6 c/o-shaped papillae per lumen on both sides, not obscuring lumen near apex more dense, cells (8-)9-11(-13) $\mu \mathrm{m}$ wide, papillae in section solid, low-conical, sometimes bifid, the same height; basal cells enlarged, rectangular, partly prosenchymatous, thin-walled, smooth, hyaline to yellowish, L/W commonly (2-)3-5(-6):1, in longitudinal rows, upwards to $c a$ half of leaf length, sometimes slightly higher, 
gradually passing over into papillate cells, along margins several rows of smaller elongate cells not forming a border. Monoicous, synoicous. Sporophytes not seen. Chromosome number unknown.

ILLuSTRATIONS. This species is well illustrated by Savicz-Lyubitskaja and Smirnova (1963: 356, figs 1 $\& 2$ ). The Bryoerythrophyllum plate (fig. 148) in Ochyra et al. (2008) represents a mixture of $B$. recurvirostrum and B. antarcticum. The Plates 1, 4-6, 14 and 28-35 belong to $B$. recurvirostrum. The Plates $2,3,7-13$ and 15-27 belong to $B$. antarcticum.

Notes. R.I.L. Smith no. 7714 is present among the figured collections but this collection was not sent on loan. R.I.L. Smith no. 7715 was sent on loan and bears the annotation 'figured specimen'.

Bryoerythrophyllum recurvirostrum var. antarcticum is well described and illustrated by Savicz-Lyubitskaja and Smirnova (1963), based on very sparse, not-fruiting collections. Seppelt (1986) concluded that this taxon is only an ecotype and identical with Bryoerythrophyllum recurvirostrum sensu stricto, but this conclusion was based on only one collection and little discussion. Ochyra and Zander (2002) treated the genera Didymodon and Bryoerythrophyllum in the Antarctic. They realized that the Bryoerythrophyllum plants from East Antarctica differ in habit from other Bryoerythrophyllum material. This is repeated by Ochyra et al. (2008: 330 discussion), who viewed the variety antarcticum as only a habit modification. They agreed with Seppelt (1986). However, I have seen no collections showing morphology intermediate between the two taxa. Only one collection seen was a mixture of $B$. antarcticum and $B$. recurvirostrum, and the two taxa were distinguishable. For the differences between the two species see the key.

Sixty-five collections of $B$. antarcticum were studied. The epithet antarcticum is available in the genus and is appropriate. Bryoerythrophyllum antarcticum shows very little variation. See also the discussion of $B$. recurvirostrum below. I consider this species to be an Antarctic endemic.

Didymodon brachyphyllus (Sull.) R. H. Zander somewhat resembles $B$. antarcticum. Rarely the two taxa grow intermixed. Didymodon brachyphyllus has a different (greenish) general tinge and a different leaf shape, bears axillary gemmae, lacks a hyaline point at the apex, and has different laminal papillae, among other differences. ${ }^{1}$

The isotype material of $B$. recurvirostrum var. antarcticum (Korotkevich 2/3) has the clavate hairs illustrated by Savicz-Lyubitskaja and Smirnova (1963: 351). Their interpretation of propagulae is indeed doubtful (Ochyra et al. 2008: 333).

Reproduction in Antarctica. All the collections seen were not fruiting. Populations with many females dominated, and males were scarcer.

HABITAT. Bryoerythrophyllum antarcticum has been collected in a wide range of habitats. It grows on dry to moist silty/sandy soil, gravel, shingle, till debris, volcanic scree, among stones, on stony floors, on cliff faces, ledges, ridges, soil on rock, shaded rock crevices, in seepage areas, on stream banks, pond and lake margins, near melt streams, margins of solifluction lobes, in overflow areas of streams, along flush below springs, on Leptogonium puberculum (a lichen), and in cracks of moss patches.

Associated mosses: Bryum pseudotriquetrum (Hedw.) P. Gaertn. et al., Distichium capillaceum (Hedw.) Bruch \& Schimp., Encalypta procera Bruch, E. rhaptocarpa Schwägr., Hennediella heimii (Hedw.) R. H. Zander, Schistidium sp.

WORLD RANGE. Bryoerythrophyllum antarcticum is restricted to Antarctica.

Distribution In AnTARCTICA. Bryoerythrophyllum antarcticum is widely distributed in Antarctica. It occurs in the maritime Antarctic from the South Orkney Islands to Alexander Island. On the eastern coast of the Antarctic Peninsula it is frequently collected on James Ross Island and has been recorded from the Oscar II Coast. On the continent it was found at two oases: Vestfold Hills and Bunger Hills. This species is collected at low elevations to $250 \mathrm{~m}$ a.s.l.

\footnotetext{
1 Recently I studied and compared the type material of Didymodon brachyphyllus (Sull.) R. H. Zander and D. gelidus Cardot. They differ distinctly from each other. Didymodon gelidus is considered an Antarctic species. In my opinion D. brachyphyllus does not occur in the Antarctic.
} 
SPECIMENS STUdied: WEST ANTARCTICA. South Orkney IsLands, Signy Island $(7 \times)$. South ShETLAND Islands $(1 \times)$, West Antarctic Peninsula, Loubet Coast $(1 \times)$. Léonie Island $(2 \times)$. George VI Sound. Alexander Island $(12 \times)$. EAST ANTARCTIC PENINSULA. JAMEs Ross Island Group. Vega Island $(2 \times)$. James Ross Island $(13 \times)$. Oscar II Coast $(1 \times)$. EAST antarcticA. Princess Elizabeth Land, Ingrid Christensen Coast (15×). Queen Mary Land. Knox Coast. Bunger Oasis $(5 \times)$.

\section{Bryoerythrophyllum recurvirostrum (Hedw.) P. C. Chen.}

Plants growing in rather loose, small, dark reddish brown tufts. Stems erect, not or sparsely branched, (0.8-)1.0-1.5(-2.0) $\mathrm{cm}$ high, rounded in transverse section with distinct central strand of smaller cells, without epidermis; rhizoids only on lower parts of stem, scattered, brown, smooth, branched, younger rhizoids lighter to hyaline. Asexual propagation, rhizoidal tubers and axillary gemmae not seen; axillary hairs hyaline, 9 cells long, in one row, each cell ca 4-5:1. Leaves regularly placed, oblong- to linear-lanceolate, (1700-)1950-2270(-2400) $\mu \mathrm{m}$ long, (440-)560$720(-840) \mu \mathrm{m}$ wide at base, with oblong, erect, slightly expanded base forming $20-30 \%$ of leaf length, close along the stem, slightly crispate when dry, leaves usually straight when wet, spreading ca $30^{\circ}$, unistratose throughout, to strongly concave, often keeled, unbroken, decurrent wings nil, apex short-acute to rounded, commonly indented or with a few teeth, more rarely entire, with 1-3 smooth, hyaline to brownish cells, margins small, recurved, mostly $1(-2)$ cells from above expanded base to apex, not always completely recurved, not bordered, often both \pm parallel; costa subpercurrent to percurrent, at base $60-80(-90) \mu \mathrm{m}$ wide, brown, smooth near base, slightly smaller towards apex, covered ventrally upwards with quadrate papillate cells, dorsally smooth below, upwards papillate (papillae as on lamina), in transverse section reniform, strongly convex dorsally, ventrally \pm flat, with median row of (2-)3-4 hyaline guide cells in one row, and weakly developed or often reduced stereid band more distinct at dorsal side, with distinct epidermis cells on ventral side; upper laminal cells in surface view commonly quadrate, somewhat rounded, evenly moderately thickwalled, with 4-6 C/O-shaped papillae on both sides per lumen, cells $8-11 \mu \mathrm{m}$ wide, in longitudinal rows, opaque, not obscuring lumen near apex more dense, papillae in section solid, low-conical, sometimes bifid, the same height; basal cells enlarged, rectangular, partly prosenchymatous, thinwalled, smooth, hyaline to yellowish-with-age tan, L/W commonly (2-)4-5:1, in longitudinal rows, somewhat bulging, upwards to ca $20-25 \%$ of leaf length, gradually passing over into papillate cells, along margins several rows of smaller, elongate cells not forming a border.

Monoicous, synoicous. Perichaetia terminal; perichaetial leaves little differentiated, elongate, sheathing, inner ones \pm smooth, not recurved. Setae erect, straight, $0.6-0.8 \mathrm{~mm}$ long, smooth, brown. Capsules exserted, erect, symmetric to slightly asymmetric, straight, cylindrical, 2180$2270 \mu \mathrm{m}$ long, smooth, brownish, thin-walled; annulus 1-3-seriate, large cells, deciduous in parts, thick-walled, vesiculose cells; operculum stout, conical, $0.5-0.7 \mathrm{~mm}$ long, straight or oblique shortrostrate; exothecial cells approximate in longitudinal rows, rectangular to isodiametric, 15-30 $\mu \mathrm{m}$ wide, 30-70 $\mu \mathrm{m}$ long, L/W (2-)3-4:1, thin-walled, becoming smaller towards mouth, forming a differentiated 3-4-seriate brownish suboral ring, dark red cells, mostly 1:1, irregular pattern; stomata few, at extreme base of urn, superficial, bicellular; peristome teeth 16 , from a low basal membrane or basal membrane absent, linear-lanceolate to filimentous, $120-150 \mu \mathrm{m}$ long, nodose-articulate, pale brown to yellowish, entire or irregularly cleft, densely fine-papillate. Spores globose, brownish, (12-)14-16(-20) $\mu \mathrm{m}$ in diameter, lightly papillate. Calyptra cucullate, naked, smooth. Chromosome number unknown for Antarctic and subantarctic material.

ILLUSTRATION. Bryoerythrophyllum recurvirostrum is well figured, for example in the flora of Allen (2002: 46).

Bryoerythrophyllum recurvirostrum is a rather stable species, with little variation observed. Commonly the plants are fruiting. It is not easy to confuse this plant with material of B. antarcticum or 
Didymodon brachyphyllus. For the differences between it and smaller states of Bryoerythrophyllum rubrum, see below in the discussion of that species.

In alpine and mountain areas $B$. recurvirostrum has been confused especially with Bryoerythrophyllum ferruginascens (Stirt.) Giacom. The latter nearly always has characteristic rhizoidal tubers, an entire leaf apex, a different leaf shape and a dioicous sexual condition. Mixtures of the taxa have very rarely been seen. The two species are distinct.

Reproduction in Antarctica. The six Antarctic collections seen were nearly all fruiting.

HABITAT. In Antarctica Bryoerythrophyllum recurvirostrum was collected in rock crevices by the shore, on outwash scree slopes, on moist soil in a seepage area, on an uncut ledge, in damp niches in a cliff face, and in meltwater niches.

Associated mosses: Amphidium sp., Bryum sp., Dicranella cardotii R. Br. bis, Pohlia sp.

WORLD RANGE. Bryoerythrophyllum recurvirostrum is widespread in the Northern Hemisphere. Apparently it is rare in the Southern Hemisphere. I saw a few collections from the Republic of South Africa and some material from Australia. Collections from South America were not seen. Apparently it does not occur there. Compare Allen (2002: 44), Zander (1994: 275; 2007: 568).

Distribution in AnTARCTICA. Bryoerythrophyllum recurvirostrum was collected only on Alexander Island. Its altitudinal range is from sea level to $c a 100 \mathrm{~m}$ a.s.l.

SPECIMENS STUDIED: Collections were only seen from WEST ANTARCTICA. GEORgE VI Sound. Alexander Island $(4 \times)$. SUBANTARCTIC. Macquarie Island $(1 \times)$. South Georgia $(1 \times)$.

\section{Bryoerythrophyllum rubrum (Jur. ex Geh.) P. C. Chen}

Plants growing in rather loose, dark reddish brown tufts. Stems erect, not to sparsely branched, (1.0-) 1.5-2.5(-3.5) cm high, rounded in transverse section, with a large central strand with smaller cells, without epidermis; rhizoids on lower parts of stem scattered, brown, smooth, branched, younger rhizoids lighter to hyaline, not in apical part. Asexual propagation: rhizoidal tubers and axillary gemmae not seen; axillary hairs hyaline, 7-12 cells long, in one row, each cell ca 4-5:1, the lower ones smaller, pale brown. Leaves rather regularly placed, lanceolate, (1300-)1700-1900 (-2000) $\mu \mathrm{m}$ long, (400-)500-800(-880) $\mu \mathrm{m}$ wide at base, usually gradually tapering from a broader semi-sheathing base towards a commonly small acuminate apex, height of sheath usually to $50 \%$ of leaf length, sometimes slightly higher, close along stem, apical region often incurved or recurved when wet, regularly asymmetrical longitudinally, when dry upper part curved mostly towards stem, when wet upper part erect spreading ca $30^{\circ}$, sometimes with slight twist, leaves unistratose throughout, to strongly concave, often keeled, unbroken, decurrent wings nil, apex usually with one smooth hyaline to brownish cell, entire, indented, or often with a few teeth at extreme tip, stems often with a few small scaly pointed leaves below, margins of larger leaves usually broadly recurved, mostly (2-)3(-4) cells from above sheath to apex, not always completely recurved, not bordered; costa subpercurrent to percurrent, sometimes with shorter or longer excurrent awn on some leaves, at base (80-)100-130(-140) $\mu \mathrm{m}$ wide, brown, smooth below, slightly smaller towards apex, covered ventrally upwards with quadrate papillate cells, dorsally smooth below, upwards becoming papillate, (papillae as on lamina), in transverse section reniform, strongly convex dorsally, ventrally \pm flat, with median row of (4-)5-6 large hyaline guide cells in one row and a weakly developed or often reduced ventral stereid band, more distinct at dorsal side, with distinct epidermis cells on ventral side; upper lamina cells in surface view commonly quadrate, somewhat rounded, evenly moderately thick-walled, with 4-6 C/O-shaped papillae on both sides per lumen, cells (8-)11-15(-19) $\mu \mathrm{m}$ wide, in longitudinal rows, opaque, papillae not obscuring lumen near apex more dense, in section solid, low-conical, sometimes bifid, the same height; basal cells enlarged, rectangular, partly 
prosenchymatous, thin-walled, smooth, hyaline to yellowish-with-age tan, L/W commonly (2-)3-5 (-6): 1, in longitudinal rows, upwards to $c a$ half of leaf length, gradually passing over into papillate cells, along margins several rows of smaller cells not forming a border. Dioicous. Sporophytes not seen. Chromosome number unknown.

ILLUSTRATION. Bryoerythrophyllum rubrum is especially well figured in Fedosov and Ignatova (2008: 29, 30).

Bryoerythrophyllum rubrum is reported here for the first time from Antarctica. The Antarctic plants are mostly rather small. These smaller specimens occur especially in the Arctic region (Fedosov \& Ignatova 2008) but I also saw this kind of material from Central Europe. It is sometimes very difficult to separate these smaller plants from B. recurvirostrum but in troublesome cases determining the sex of the plant can prove conclusive. This requires a careful search of individual stems, with the leaves scraped. In most cases 10 to 15 individual stems from a collection were examined this way.

Reproduction In Antarctica. Thirteen collections were identified from this region. None were fruiting. Only female populations were found.

HABITAT. Bryoerythrophyllum rubrum has been collected on dry to moist sandy soil, on stony ground, among boulders, along margins of solifluction lobes, in a limestone area, in a lichen and moss community with boulders along a beach, on a rock face, on slopes, in crevices, and colonizing mineral soil.

Accompanying mosses: Bryum spp., Distichium sp. and Encalypta sp.

WORLD RANGE. Bryoerythrophyllum rubrum is a bipolar species. It occurs in Arctic and alpine mountain areas from $c a 2500$ to $4000 \mathrm{~m}$ a.s.l. or somewhat higher. In Arctic regions it is found at low altitudes. I saw collections from Central Africa, Tanzania (Mt. Kilimanjaro), Asia, SE Afghanistan, the Russian Federation (Caucasus, Siberia), Himalaya (Bhutan), China (Prov. Qinghai, Sichuan, Xinjiang, Xizang, Yunnan), India (Sik- kim), Nepal, Pakistan (Northern Areas), Mongolia, Central and Northern Europe.

Distribution in Antarctica. So far, Bryoerythrophyllum rubrum has been infrequently collected, mainly in West Antarctica. It occurs in the maritime Antarctic from the South Orkney Islands to Alexander Island. In Eastern Antarctica it has rarely been collected. On the continent it was found at an oasis: Vestfold Hills. Its elevation range in Antarctica extends from sea level to $75 \mathrm{~m}$ a.s.l.

SPECIMENS STUdied: WEST ANTARCTICA. SOUTH ORKNEY IsLANDS. Signy Island $(5 \times)$. SOUTH SHETLAND ISLANDS. KING GEORGE ISLAND $(1 \times)$. WEST ANTARCTIC PENINSULA. GeORge VI Sound. Alexander Island $(6 \times)$. EAST ANTARCTICA. Princes ElizABETh LAND. Ingrid Christensen Coast. Langeset Peninsula, Vestfold Hills $(1 \times)$.

ACKNOWLEDGEMENTS. I thank Professor Ryszard Ochyra (Kraków, Poland) for making the material available, two anonymous reviewers for helpful suggestions on the manuscript, the staff of L (Leiden) for placing at my disposal the Bryoerythrophyllum material housed there, and Heribert T. Köckinger (Austria) for very kindly sending some duplicates of Bryoerythrophyllum rubrum, the smaller specimens, from his herbarium.

\section{REFERENCES}

Allen B. 2002. Moss Flora of Central America, Part 2. Encalyptaceae-Orthotrichaceae. Monogr. Syst. Bot. Missouri Bot. Gard. 90: 1-699.

Brummitt R. K. \& Powell C. E. (eds) 1992. Authors of plant names. A list of authors of scientific names of plants, with recommended standard forms of their names, including abbreviations. Royal Botanic Gardens, Kew.

Fedosov V. E. \& Ignatova E. A. 2008. The genus Bryoerythrophyllum (Pottiaceae, Bryophyta) in Russia. Arctoa 17: 19-38.

Ochyra R., Lewis Smith R. I. \& BednareK-Ochyra H. 2008. The Illustrated Moss Flora of Antarctica. Cambridge University Press, Cambridge, U.K.

OChYRA R. \& ZANDER R. H. 2002. The genera Didymodon and Bryoerythrophyllum (Pottiaceae) in Antarctica. J. Bryol. 24: $33-44$.

SaVicz-Lyubitskaya L. I. \& SMiRnova Z. N. 1963. A contribution to the biology and geography of Bryoerythrophyllum recurvirostre (Hedw.) Chen - A new species in the 
bryoflora of Antarctica. Bot. Zhurn. (Moscow \& Leningrad) 48: 350-361 (in Russian with an English summary).

SePpelt R. D. 1986. Bryophytes of the Vesthold Hills. In: J. PICKARD (ed.), Antarctic oasis. Terrestrial environments and history of the Vestfold Hills, pp. 221-245. Academic Press, Sydney.

ZANDER R. H. 1994. Bryoerythrophyllum. In: A. J. SHARP,
H. Crum \& P. M. Eckel (eds), The moss flora of Mexico, Part one, Sphagnales to Bryales. Mem. New York Bot. Gard. 69: 273-283.

ZANDER R. H. 2007. Bryoerythrophyllum P. C. CHEN. In: Flora of North America Editorial Committee (eds), Bryophyte Flora of North America, North of Mexico. 27. Bryophytes: Mosses. 1: 565-569. Oxford University Press, New York.

Received 29 September 2014 